\title{
Artigo de Opiniño
}

\section{Disability in Olympic Games}

\section{Deficiência em Jogos Olímpicos}

\author{
Lucas André Borato', Carlos Bandeira de Mello Monteiro', \\ Deisy de Freitas Lima Ventura ${ }^{1}$, Marcelo Massa ${ }^{1}$
}

DOI: http://dx.doi.org/10.11606/issn.2317-2770.v24i1p44-47

\begin{abstract}
Borato LA, Monteiro CBM, Ventura DFL, Massa M. Disability in Olympic Games. Saúde, Ética \& Justiça. 2019;24(1):44-7.

ABSTRACT: Paralympians' participation in the Olympic Games is marked by intense debate. To evaluate disabilities, we should avoid literal definitions and rather consider the diverse factors that may influence a person's functions and functionality. This article analyses two cases of disabled athletes: Oscar Pistorius and Alan Fonteles. We understand that, if an athlete, despite of any disability, feels he or she is able to compete with others, this athlete should not be prohibited to do so. Moreover, without scientific evidence that an athlete has advantages over others, people with disabilities should be allowed to participate in any championship.
\end{abstract}

KEY WORDS: Athletes; Disabled Persons; Sports.

1. University of São Paulo, SP, Brazil.

Address: Rua Arlindo Béttio, 1000 - Vila Guaraciaba, São Paulo - SP. E-mail: lucas.borato@usp.br, carlosmonteiro@, usp.br,mmassa@usp.br,deisyflv@gmail.com 


\section{INTRODUCTION}

D isabilities in sports have been in the spotlight since the beginning of the $20^{\text {th }}$ century. People who participate in disabled sports competitions are now seen as athletes and not only as disabled people ${ }^{1}$. The $20^{\text {th }}$ century introduced sports opportunities for people with disabilities, and federations have been created for different types of impairments and disabilities $^{2}$. Disability sports first appeared in the late $19^{\text {th }}$ century, with the Sport Club for the Deaf, founded in Berlin, in 1888. Sometime later, the Belgium National Sports Federation for the Deaf was created in 1924. In the same year, the First International Silent Games were held in Paris ${ }^{3,4}$. Ludwig Guttmann played an important role in the history of disability sports. He was a Jewish neurosurgeon who arrived in Britain as a refugee from Germany. There, he initiated a rehabilitation program at the Stoke Mandeville Hospital to aid disabled people and

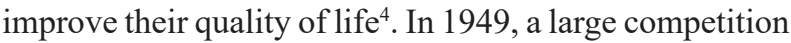
took place in Stoke Mandeville, and rapidly these games gained international dimensions. Soon after, they were nicknamed the Paralympics ${ }^{4,5}$.

Athletes with disabilities have been present in Olympic Games since 1904. Since then, 28 disabled athletes have competed in the Olympics. Oscar Pistorius was present in the London 2012 Games in both the Olympic and Paralympic competitions ${ }^{5}$ and is probably the most famous athlete to have done so. His participation in the Olympics lead to intense debate and attracted the media's attention ${ }^{6}$. This athlete has a bilateral bellowknee amputation- and shows great performance in 100 , 200 and $400 \mathrm{~m}$ sprint runs. ${ }^{5}$. Pistorius' case provides elements that lead to an ethical discussion about the presence of Paralympic athletes within Olympic Games. The objective of this article is to discuss the participation of disabled people in the Olympic and Paralympic Games. Two cases of bilateral below-knee amputees will be presented to illustrate this issue.

\section{What is disability?}

To evaluate disabilities, we should avoid literal definitions and rather consider the individual's environment, life history, background, perceptions, activities, and other factors that may influence a person's functions and functionality. Dysfunction and health differences are referenced on what is understood as the normal functioning. They may be due to accidents, genetics, and mutations. Disabilities are thus dysfunctional deviations from what is considered as normality? ${ }^{7}$. It is also an umbrella term that covers impairments, activity limitations and participation restrictions ${ }^{8}$.

According to Edwards ${ }^{6}$ (2008), the International Association of Athletics Federation (IAAF) and the
International Olympic Committee (IOC) adopt the World Health Organization (WHO) definition of disability and activity limitation. The author, however, stands with Nordenfelt's (1993) definition of disability, according to which: "if one can do everything that is important to one, then one is not disabled" ${ }^{\prime \prime}$. In the $\mathrm{WHO}^{8}$ (2001) classification of function, disability and health states, disability is the outcome of complex interrelations between a person's health conditions, personal factors and external factors. Both views on disability are valuable for the present discussion.

\section{Oscar Pistorius}

Oscar Pistorius is a bilateral below-knee amputee athlete from South Africa. He won the $200 \mathrm{~m}$ sprint run gold medal in Athens, 2004, breaking a world record at the time; gold medals in the $100 \mathrm{~m}, 200 \mathrm{~m}$, and $400 \mathrm{~m}$ runs in 2008 in Beijing; and competed in both Olympic and Paralympic Games in London, 2012, winning a silver medal for the $200 \mathrm{~m}$ run and being classified for the $400 \mathrm{~m}$ semi-finals in the Olympics ${ }^{5,6,9}$. Before finally participating in the Olympics, Oscar Pistorius had been prohibited of competing against able-bodied athletes by the International Association of Athletics Federation, on the grounds that his J-shaped blades gave him advantage over other competitors. This decision was overturned by the Court of Arbitration for Sports9.

Regarding this issue, the IAAF Rule 144.3 forbids the usage of any technical device that gives the user advantage over other athletes. In addition, Rule 125.8 states that:

\footnotetext{
Where an athlete with a physical disability is competing in a competition under these Rules, the appropriate Referee may interpret, or allow a variation from, any relevant Rule (other than Rule 144.3) to enable the participation of the athlete provided that such variation does not provide the athlete with any advantage over another athlete competing in the same event. ${ }^{10}$.
}

$\operatorname{Edwards}^{6}(2008)$ did an incredible work answering various arguments against the participation of Oscar Pistorius in Olympic Games. These arguments ranged from statements that Oscar Pistorius had unfair advantage due to his disability to suggestions his participation might lead others to amputate their own legs as well. Regarding these arguments, Jones and Wilson ${ }^{9}$ (2009) affirm that there is a difficulty in defining advantages in sports as fair or unfair. Moreover, despite the IAAF's conclusion that Pistorius could have a mechanical advantage of more than $30 \%$ using the prostheses ${ }^{11}$, the study fails to analyse performance during all the phases of a sprint ${ }^{12,13}$, as well as other disadvantages that he might have'.

To van Hilvoorde and Landeweerd ${ }^{7}$ (2008), from 
a socio-cultural perspective, Paralympic and Olympic athletes are not that different, and genetics may result in talent or disability. The argument that Oscar Pistorius has an unfair advantage is incorrect and the blades probably bring more disadvantages than advantages ${ }^{6}$. Athletic performance is a complex concept and cannot be easily defined or measured. People should see sports as a manner for athletes of all levels to achieve their best performance within their individual variations and not judge if those variations are superior or inferior ${ }^{9,14}$.

Finally, the literature is controversial regarding the positive or negative effects of Pistorius' blades in his sprint performance. Potthast and Brueggermann ${ }^{15}$ (2010) state that the biomechanics of bilateral below-knee amputees and able-bodied people sprinting demonstrates differences. The authors affirm that Oscar Pistorius runs with smaller vertical displacement in the phase of maximal speed than able-bodied sprinters and that he has a lower deceleration during the first part of the stance phase, which leads to less propulsion impulse in the second stance phase. Meanwhile, Weyand et al. ${ }^{16}$ (2009) demonstrated that running with lower-limb prostheses could be at the same time similar physiologically and different mechanically to non-prosthetic runners. Furthermore, another study comparing sprinters who had only one prosthetic lower limb found that in the amputated leg the stance average vertical ground reaction force is around nine percent less than in the non-amputated leg. The authors also reported that the leg swing time was similar between amputated and non-amputated legs at any given speed and that both leg swing times were equivalent to what had been previously described for non-amputee sprinters ${ }^{17}$. Additionally, Zettler ${ }^{18}$ (2009), analysing Pistorius' case, argues that the Court of Arbitration of Sports correctly permitted the athlete to participate in games with able-bodied competitors.

\section{What about Alan Fonteles?}

Alan Fonteles is a Brazilian sprinter and, like Oscar Pistorius, a bilateral below-knee amputee. He was amputated when he was 21 days old and started in sports at eight, without using sports prostheses ${ }^{5}$. Today, Fonteles is seen as the best amputee sprinter in the world, holding the world record in the $100 \mathrm{~m}$ T43 class, with a time of $10.57 \mathrm{~s}^{19}$. Fonteles defeated Pistorius during the 2012 London Games, running in the T44 class; he completed the race in $21.45 \mathrm{~s}$, also winning the world record ${ }^{20}$. At the time, the Brazilian media gave almost no attention to the fact that he thought of competing in the Olympics's. This shows the lack of media exposure to Paralympian athletes and Paralympic Games.

Despite Pistorius and Fonteles both being bilateral below-knee amputee sprinters, they became involved in an altercation. Pistorius made a formal complaint to the International Paralympic Committee about Fonteles' prostheses, claiming the prostheses gave Fonteles advantage $^{21}$. One may think this was a hypocritical of him, since Pistorius had faced similar allegations before. However, athletes who compete in Olympic and Paralympic Games do not want to lose. In 1982, Goldman et al.22(1984) proposed a dilemma for athletes, asking if they would take a pill that would guarantee them the gold medal but make them die five years afterwards. Mirkin ${ }^{23}$ (1984) points out that, in a survey asking runners this question, the results demonstrated that approximately $50 \%$ of the athletes would take the pill. Indeed, Gonzalez et al. ${ }^{24}(2018)$ conducted a study that demonstrated athletes are prompt to accept fatal risks to win a gold medal. Thus, if one is likely to put oneself at risk, Pistorius' hypocritical attitude towards his colleague as mean of obtaining victory is more understandable.

\section{FINAL CONSIDERATIONS}

In this opinion article, we discussed some issues regarding the participation of Paralympic Athletes in the Olympic Games. The ethical discussion that arises from the possible advantages and disadvantages related to individual variation cannot be restricted to definitions only. If an athlete feels he or she is able to compete with others despite of any disability, this athlete should not be prohibited to do so. Thus, without clear scientific evidence proving that one athlete has advantage over others, people with disabilities should be able to participate in any championship. Thereby, for the sake of sports, let them run.

Borato LA, Monteiro CBM, Ventura DFL, Massa M. Deficiência em Jogos Olímpicos. Saúde, Ética \& Justiça. 2019;24(1):44-7.

RESUMO: A participação de portadores de deficiência em Jogos Olímpicos é marcada por intenso debate. Para avaliar deficiências devemos evitar definições literais e considerar os diversos fatores que podem influenciar nas funções e funcionalidades de uma pessoa. Este artigo analisa dois casos de atletas portadores de deficiências: Oscar Pistorius e Alan Fonteles. Nós entendemos que, se um atleta, apesar de portar alguma deficiência, sente-se apto para competir com outros atletas, ele não deve ser impedido de fazê-lo. Além disso, sem evidências científicas claras que um atleta tenha vantagem sobre os outros, pessoas com deficiência devem poder participar de qualquer competição.

DESCRITORES: Atletas; Pessoas com deficiência; Esportes. 


\section{REFERENCES}

1. DePauw KP, Gavron SJ. Disability sport. $2^{\text {nd }}$ ed. United States of America: Human Kinetics; 2005.

2. Fay T, Wolff E. Disability in sport in the twenty-first century: Creating a new sport opportunity spectrum. Boston UnivInt Law J. 2009;27(2):231-48.

3. Séguillon D. The Origins and Consequences of the First World Games for the Deaf: Paris, 1924. Int J Hist Sport. 2002;19(1):119-36. DOI:https://doi. org/10.1080/714001694.

4. Gold JR, Gold MM. Access for all: the rise of the Paralympic Games. J R SocPromot Health. 2007;127(3):133-41. DOI: https://doi.org/10.1177/1466424007077348

5. Mataruna-Dos-Santos LJ, Guimaraes-Mataruna AF, Range D. Paralympians competing in the olympic games and the potential implications for the paralympic games. Br J Ed Tech Soc. 2018;11(1):105-16.DOI http://dx.doi. org/10.14571/brajets.v11.n1.105-116

6. Edwards SD. Should Oscar Pistorius be Excluded from the 2008 Olympic Games? Sport Ethics Philos. 2008;2(2):112 25. DOI: https://doi.org/10.1080/17511320802221802

7. van Hilvoorde I, Landeweerd L. Disability or Extraordinary Talent-Francesco Lentini (Three Legs) Versus Oscar Pistorius (No Legs). Sport Ethics Philos. 2008;2(2):97-111. DOI: https://doi.org/10.1080/17511320802221778

8. World Health Organization. International Classification of Functioning, Disability and Health: ICF. Geneva: WHO; 2001.

9. Jones C, Wilson C. Defining advantage and athletic performance: The case of Oscar Pistorius. Eur J Sport Sci. 2009;9(2):125-31.

10. International Association Of Athletics Federations. Competition Rules 2018-2019. Monaco: IAAF; 2017.

11. World Athletics. Oscar Pistorius - Independent scientific study concludes that cheetah prosthetics offer clear mechanical advantage [Internet]. Monte Carlo; 2008 [Access in 2019 May 09]. Available at: https://www. worldathletics.org/news/news/oscar-pistorius-independentscientific-stud-1

12. Wolbring G, Tynedal J. Pistorius and the media: missed story angles. Sport Technol. 2013;6(4):177-83. DOI: https://doi.org/10.1080/19346182.2013.826666

13. Dyer B. The controversy of sports technology: a systematic review. Springerplus [Internet]. 2015 [Access in 2019 Mar 13];4(524):1-12. Available from: https://springerplus. springeropen.com/articles/10.1186/s40064-015-1331-x
14. Wolbring G. Paralympians Outperforming Olympians: An Increasing Challenge for Olympism and the Paralympic and Olympic Movement. Sport Ethics Philos. 2012;6(2):25166.

15. Potthast W, Brueggemann G. Comparison of sprinting mechanics of the double transtibial amputee Oscar Pistorius with able bodied athletes. In: $28^{\text {th }}$ International Conference on Biomechanics in Sports; 2010; Michigan, USA. Germany: ISBS - Conference Proceedings Archive; 2010.

16. Weyand PG, Bundle MW, McGowan CP, Grabowski A, Brown MB, Kram R, et al. The fastest runner on artificial legs: different limbs, similar function? J ApplPhysiol [Internet]. 2009 [Access in 2019 Mar 09];107(3):90311. Available from: https://www.physiology.org/doi/ pdf/10.1152/japplphysiol.00174.2009

17. Grabowski AM, McGowan CP, McDermott WJ, Beale MT, Kram R, Herr HM. Running-specific prostheses limit ground-force during sprinting. Biol Lett [Internet]. 2010 [Access in 2019 Mar 09];6(2):201-4. DOI: https://doi. org/10.1098/rsbl.2009.0729

18. Zettler PJ. Is it cheating to use cheetahs: The implications of technologically innovative prostheses for sports values and rules. Boston UnivInt Law J. 2009;27:367-409.

19. Hobara H. Running-specific prostheses: The history, mechanics, and controversy. Journal of the Society of Biomechanisms. 2014;38(2):105-10.

20. Knoploch C. Alan Fontelessupera Oscar Pistorius e é ouronos 200m emLondres[Internet]. Rio de Janeiro; 2012 [Access in 2019 May 09]. Available at: https://oglobo. globo.com/esportes/alan-fonteles-supera-oscar-pistorius-eouro-nos-200m-em-londres-5980885

21. Bull A. Oscar Pistorius angry at shock Paralympics $200 \mathrm{~m}$ loss[Internet]. United Kingdom; 2012 [Access in 2019 May 09]. Available at: https://www.theguardian.com/sport/2012/ sep/03/paralympics-oscar-pistorius-angry-loss

22. Goldman B, Bush PJ, Klatz R. Death in the Locker Room: Steroids and Sports. $1^{\text {st }}$ ed. London: Century Publishing; 1984.

23. Mirkin G. Death in the Locker Room: Steroids and Sports. JAMA [Internet]. 1984 [Access in 2019 Apr 05];252(19):2771. DOI: https://doi.org/10.1001/ jama.1984.03350190063026

24. González JM, Johnson FR, Fedoruk M, Posner J, Bowers L. Trading health risks for glory: a reformulation of the Goldman Dilemma. Sports Med. 2018;48(8):1963-9. DOI: https://doi.org/10.1007/s40279-018-0881-9 